\section{FACTORS OF AGRICULTURAL PRODUCTION IN THE BRITISH COLONIAL EMPIRE*}

\author{
By SiR FRANK STOCKDALE, G.C.M.G., C.B.E. \\ Adviser on Development Planning, Colonial Office
}

C IONSIDERABLE interest is now being taken by 1 Great Britain in colonial development. This interest has been further stimulated by the Govern. ment's decision during the past year to undertake the East African groundnut scheme and to establish a Colonial Development Corporation and an Overseas Food Corporation. The latter, when constituted, will take over the operations of the East African ground-nut scheme and start other food production projects overseas, while the Colonial Development Corporation will deal with developmental projects of a widely varying character throughout the colonial territories-the importance of which has been emphasized in recent months by the difficulties which are being experienced by Britain in the balance of dollar payments.

It is, however, well to realize that this decision by the Government to establish a Colonial Development Corporation is but another advance in Britain's colonial policy, which is designed to improve the standard of living of the colonial peoples, to extend their social services and to advance political selfgovernment. The British people are convinced that the standards of life of the colonial peoples must be raised and that better economic standards in colonial territories will provide expanding markets and a general improvement of world trade.

Improved standards of life cannot be obtained or better social services maintained without expanded production. Indeed, the emphasis in the activities of Colonial Governments in the future is certain to be in the developmental field, and to be directed towards the utilization of the natural resources of the territories to the fullest extent possible, coupled with a general advancement of their peoples.

Looking at the colonial territories as a whole, the one outstanding feature which calls for comment is the very considerable increase of population during the past twenty to thirty years. It is rapidly becoming apparent that the present systems of production may very shortly be unable to provide sufficient food for satisfactory nutritional standards for these increasing populations and that marked changes in the methods of production must be made. In certain places, particularly in Eastern and Central Africa, soil erosion has assumed alarming proportions, and considerable areas, through pressure on the land and by poor systems of agricultural husbandry and stock keeping, have been rendered incapable of further production for many years.

Food will, undoubtedly, figure prominently in the requirements of the future and must be given the highest place in colonial policy. At the same time, if standards of living are to be raised, commercial crops must be grown and a more diversified production established.

I propose here to limit myself to a consideration of some of the factors which influence agricultural production under colonial conditions. They may be dealt with under the following headings: climate, soils, water, systems of agriculture, use of livestock,

* From a Friday Evening Discourse at the Royal Institution delivered on January 23. crop varieties, pests and diseases of man and his stock and crops, marketing arrangements and social organisation.

\section{Climate}

The climates of the British Colonial Empire range from the super-humid of the tropical rain belt with its heavy forest, through the humid with its lesser forest or parkland vegetation to the sub-humid with grasscovered savannas and thence to semi-arid steppe or desert with sparse vegetation. Climate, after all, plays the part of master influence on agricultural activities and production, and it determines not only the major soil zones, but also the systems of agriculture which prevail.

In the eastern group of Colonies, the climate of Malaya, Sarawak and North Borneo may be classified as super-humid and that of Ceylon either super-humid, humid or sub-humid according to aspect and altitude. In the West Indies, and the continental territories of British Guiana and British Honduras, the range is similar to that of Ceylon, but there are occasionally years of serious drought.

A study of Africa reveals wide climatic belts which range from super-humid to the semi-arid. Types of vegetation and the agricultural crops correspond to a greater or lesser degree with the different climatic belts. In West Africa, dense equatorial forest covers the coastal regions of the Gold Coast and Nigeria, and extends throughout French Equatorial Africa into the Congo basin. North of this equatorial rain forest occur zones which pass from humid and subhumid to arid, with corresponding tall grass savanna, dry savanna or desert. In East Africa, humid regions occur as coastal or lake belts, sub-humidity prevailing elsewhere except where influenced by altitude. In Uganda, the area with a humid climate exceeds that under sub-humidity which is characteristic of the other East African territories. At the higher altitudes in East Africa, as well as in the Central African territories, there are zones of mountain forest and grasslands with variable rainfall.

Production in the tropical rain belt with an annual rainfall in excess of 80 in. includes timbers and forest products, oil palms, coconuts, rubber, cacao, bananas, sugar, rice and certain root crops, whereas the production of the drier forest, parkland or grass savanna areas with rainfalls ranging from 30 in. to 60 in. includes coffee, cotton, yams, maize, millets, groundnuts and livestock, and in the areas of low rainfall millets are grown and livestock are found to predominate. In the higher altitudes with rainfalls of 60 in. or more, tea and wattle flourish, and where the rainfall is lower, coffee and some of the crops of temperate zones thrive.

\section{Soils}

These cover a wide range and naturally vary in composition according to the nature and age of the rocks from which they have derived. Laterites are common. They contain an appreciable quantity of iron concretions--sometimes resembling lumps of iron ore and sometimes small pebbles. They are caused by the leaching of iron salts from the upper soil layers and their subsequent re-oxidation around particles of quartz. In many areas, particularly where the climate is humid or sub-humid, definite hard pans are formed and these have to be watched for with care. Tropical soils generally are acid in reaction, especially in the wetter areas and where not derived from limestone. Some crops require soils of 
acid reaction for maximum production and will not thrive when the lime content in the soil is high, while others only prosper where the soils are neutral or only slightly acid in reaction. Throughout the soils of the tropics a deficiency of nitrogen is widespread. Phosphatic deficiency also occurs over wide areas.

Climatic factors have their influence upon soil formation; but in general the soils correspond closely with the geological formations and are the product of the rapid weathering of the rocks under the influence of rainfall and high temperatures. There are marked differences between the formation of soils under tropical conditions and those of the temperate regions, although the fundamental scientific principles are the same. Such factors as depth of soil, moisture content, drainage, soil structure and tilth, and the nature of the rocks from which they have derived, all have their influence. The interdependence of these several factors must be recognized.

In the wetter areas of the tropics, weathering is much more rapid than in temperate zones, and the biological activities in the soils are speeded up. Under super-humid conditions a dense growth of rain forest exists; but this luxurious cover must not be taken as an index of soil fertility, because as soon as the forest cover has been removed and the land brought into cultivation, there is a rapid fall in fertility. Nitrogen is leached rapidly by the heavy rains, and the forest floor cover of decaying vegetation is rapidly oxidized and lost. It is, indeed, now recognized that in the very wet areas, where there is no well-marked dry season, it is essential for land to be kept under cover of growing vegetation if soil fertility is to be maintained. Tree crops are the best suited for cultivation under these conditions.

Humus is the regulator of good conditions of tilth and of water distribution under the conditions prevailing in the wet tropics, and with perennial crops under a heavy and well-distributed rainfall, green manuring is the most suitable means of maintaining humus. The chief requisite for the successful use of green manures is the availability in the soils of sufficient moisture to ensure decomposition. A green manure crop must, however, be handled with skill so that the carbon and nitrogen cycles are dovetailed with the growth of the main crop.

It may here also be mentioned that one of the striking features of native agricultural systems in the wet tropics is the system of mixed cropping. There is sound justification for this practice.

In the zones of sub-humid climates the sequence of events is somewhat different from those occurring in the super-humid zones. Here there are marked dry seasons when chemical and biological activities are slowed down through inadequate supplies of soil moisture. Green manuring can be used under these conditions only with care, and in areas where the rainfall is poorly distributed their use may indeed be detrimental because of the drain which these green manures make, during their periods of growth, upon the soil moisture. In areas where there are marked contrasts between wet and dry seasons and where high temperatures prevail in the dry periods, it is difficult to maintain under a system of cropping the content of organic matter in the soils; but these soils do not appear to lose fertility so rapidly as the soils in the wetter areas because the losses from leaching are so very much less. In dry areas, much value has been derived from mulching, and in certain places agricultural production has been dependent upon the adoption of this practice.
In soils in the sub-humid zones, the available nitrogen is greater at the end of a long dry and hot period than at the beginning of the drought. Systems of bare fallow between crops are therefore used. This nitrogen is mainly in ammoniacal form; but with remoistening by rain a rapid biological conversion to nitrate takes place and rapid plant-growth results therefrom. One has only to see the rapid flush of grass after the first rains to realize the importance of this store of nitrogen, and where agriculture is practised the aim must be to make the fullest use of it. Weed-growth flourishes in such conditions and causes losses in crops unless promptly and adequately dealt with. It is this weed-growth which peasant cultivators often find it difficult to control.

Soils in the sub-humid zones are also prone to lose crumb structure and to suffer severely from erosion. Examples are to be found in East Africa.

The use of grass leys has been shown in Uganda and elsewhere to improve the crumb structure of the soil, and this system is now extending there and being tried elsewhere. Grass also is a natural good protection against erosion. In short-grass country, overgrazing of stock can, however, easily bring disaster. It has also been found in many parts of the tropics that farm practices may accelerate the destruction of tilth and that cultivation in excess of what is required to control weeds may depress crop yields. Hence the general tendency to reduce cultivations to those which are necessary for the destruction or suppression of weed-growth. It is under sub-humid conditions that the majority of the lands of colonial territories in Africe are found, and while mixed farming is likely to be the best system for peasant production, other systems involving the use of grass leys and fertilizers will have to be worked out for large-scale production.

\section{Water}

While some colonial territories have given special attention to the question of water development, there are many others in which much remains to be done. In general, there is a great scarcity of rural water supplies. Populations in certain areas are crowded together because of the limited development of water over a wider area, and in East Africa there is a serious maldistribution of livestock as a consequence of the inadequacy of the supplies of water for such stock.

Irrigation is a recognized part of the agricultural system in the eastern territories, where rice-growing is an old-established occupation; in Malaya, drainage control must be linked with irrigation. This is also the case in British Guiana on the flat coastal lands and in the coastal and internal swamp areas of Sierra Leone. Irrigation is practised in certain of the drier parts of Mauritius and also in Cyprus, where considerable success has recently been achieved with small village irrigation schemes. In areas where rainfall is normally erratic or deficient or where population increases are causing pressure on the land. the further development of irrigation is essential if increased production is to be achieved.

\section{Systems of Agriculture}

These range from highly organised systems under estate management, where considerable use of the services of science has been made, to the most primitive of systems of 'shifting cultivation' for the production of subsistence foods. In the West Indies, science can justify a claim to have been responsible for increased yields of sugar of the order of 25-30 per 
cent, and in the rubber industry of the Far East, production yields of double or treble those previously obtained from unimproved seedling growths have been achieved since the vegetative propagation of improved strains of rubber has been adopted.

At the same time, it may be safely assumed that productivity could easily be increased by a further 25 per cent in large-scale operations and up to 50 per cent in the smaller holdings from greater efficiency in the methods of husbandry.

At the bottom of the scale is the system of 'shifting cultivation' which is the basic system of subsistence agriculture. This system is still the standard practice of a very large number of the peasant cultivators of Africa and also of other tropical territories in areas where rice cultivation has not been established. These peasant cultivators, in sparsely populated areas, have plenty of land at their disposal, and a system of rotation of land has preference over rotation of crops. This is understandable when land is plentiful and where the people have only the hoe and the axe, in addition to fire, as their aids to the production of their food requirements. They may choose their lands with care, and they may be skilled in the choice of plant indicators of good soils; but their operations are restricted by the tools at their disposal, by the fall in soil fertility which follows the first year of cultivation and, most of all, by their inability to deal with the luxuriant weed-growth, which becomes really troublesome in the second season. It is this weed-growth which is generally the controlling factor in shifting cultivation in the wet tropics.

In some parts of Africa there have been natural evolutions from the primitive system of 'shifting cultivation' to a more settled form of continuing production, especially where cash crops have been established; but in some places it has been necessary to arrange for new settlements because of the low fertility to which the land has been reduced. In such cases, it is not unknown for reluctance to be shown to the abandonment of land occupied by the tribal group in favour of a movement to new sites, because of the beliefs of the people; and this has been even more marked when the occupation of the new land has been conditioned by arrangements for its proper use.

Advances in tropical agricultural systems have, however, in general been most rapid under European management, or where there has been a mingling of large-scale and peasant production. The progress made in the past twenty years has been considerable; but the needs of the next decade will necessitate a revolution in methods of production, especially if the standards of life of the colonial peoples are to be markedly advanced. The hoe system of agriculture will have to give place to other methods ; and the introduction of mechanized aids and of fertilizers is inevitable.

Estate cultivations have made increasing use of fertilizers ; but the experimental work with fertilizers has been mainly confined to the requirements of the cash or export crops. Little has been done where food crops are concerned except in regard to rice, largely because of the low unit monetary values of these crops. Some useful work has, however, been done in Northern Nigeria and in isolated instances elsewhere; but a wide scheme of fertilizer trials, planned in accordance with the most modern techniques for field experiments, has recently been started in East Africa.

\section{Use of Livestock}

Agricultural progress in Western countries has been linked with the use that has been made of livestock, and this has led to the development of important animal industries. In the colonial territories livestock industries are but little developed. It is true that considerable use is made of buffaloes and cattle for draught purposes, as well as in connexion with rice cultivation in the Eastern colonial territories and also for the production of milk and milk products. An important livestock industry also is developing in the highlands of Kenya, where European strains, especially when crossed with selected animals from the native stock, thrive satisfactorily, and where a number of co-operative creameries have been established. Similarly, European strains form the basis of the livestock in the West Indian colonies, and a thriving dairy industry has been developed in Jamaica since the establishment some seven years ago of a milk condensary.

This use of European strains of livestock in tropical areas cannot, however, be general, and reliance has to be placed on the improvement of the native breeds. The heat-regulating mechanism of European cattle is adapted to life in temperate climates, and the high ranges of atmospheric temperatures and humidity, especially where there is a low rate of air movement, cause adverse physiological reactions under tropical conditions. The stock have higher body temperatures, Jigher respiration-rates and a change in the pulserate. European breeds are not suited to those areas in colonial territories where high average tempera. tures and high humidity prevail, and under these conditions they can only be kept in full productivity when they are maintained under artificial conditions of controlled temperatures, as they were before the War in some special dairies in Singapore. It is only at the higher altitudes where temperate conditions prevail, or in the island territories where air movements are considerable, that European stock can be satisfactorily maintained if the higher plane of nutrition required is available. Even in these conditions it is necessary to provide a sufficiency of shade and to see that the stock are not subjected to the full blaze of the tropical sun between the hours of 10 a.m. and 4 p.m. The crossing of European stock with Indian or the indigenous breeds of Africa has been fairly widely practised. This system can, however, only be used in restricted areas and, in general, selection from the indigenous stock will be the soundest policy.

So far, the livestock of the colonial territories of Africa have been little used in agriculture. The herds are grazed on the natural pastures and move over fairly wide ranges from area to area according to the seasons and the nature of the herbage. Their owners are reluctant to sell them, and agriculturists frequently have difficulty in acquiring stock for their farm needs.

Where there is overstocking, soil erosion and land deterioration can be traced directly to the damaging effects of overgrazing and excessive trampling of the land; but experimental trials have shown that where controlled grazing is practised and where stock numbers are limited to the carrying capacity of the land, considerable improvements can be effected.

In some colonial territories there has been an extension of the use of livestock for the manuring of agricultural land, for the production of dairy products, for the conversion of farm wastes and for purposes of 
draught. In African territories, however, numbers are placed before quality because of the fear of losses from disease and because the social status of their owners in the community is judged by the number of stock owned. The problem of livestock in Africa is full of difficulties; but it must be tackled resolutely and with imagination if the present damage to land is to be checked, and if an animal industry of full value to the inhabitants of the territories concerned and to the world in general is to be established.

Livestock management by colonial peoples is still very backward even where mixed husbandry or dairying has been established; but it is general to find that peasant farmers with livestock are better off and live at higher standards than do those who possess no livestock.

\section{Crop Varieties}

Some reference has already been made to the increased yields which have been secured from the use of improved seed or planting material. In no sphere of the application of science to tropical agriculture has more progress been made.

Sugar cultivations now depend almost entirely upon the growth of improved strains of seedling varieties. Cotton production also requires the continuing production of new types suited to the particular conditions under which they are grown. Rubber growing has been transformed by the selection of high-yielding strains which, when proved, have been propagated vegetatively or planted in special isolated gardens for the production of self-fertilized seed. Similar progress has been made with coffee, cacao and, to a lesser degree, with tea, while the successful cultivation of tung depends entirely upon selection work. Many other examples could be quoted.

In certain areas, breeding work has been done with tropical food crops; but the progress in this field has not been so pronounced as could have been hoped for. The genetics of the genus Musa, to which the banana belongs, has received considerable attention at the Imperial College of Tropical Agriculture in Trinidad and also in Jamaica, where large numbers of seedlings have been produced. None of these, as yet, fully meets the commercial requirements of the trade, and a further search for new breeding material is shortly to be made. In Barbados, all sweet potatoes now grown are of seedling origin, and the yields are markedly in excess of those obtained from the earlier standard varieties. Similarly, strains of cassava which are improvements on the earlier types have also been evolved. Marked improvements have been made with rice in Ceylon, in Malaya and in British Guiana. The millets have not, so far, received the attention that should have been given to them, and it is hoped that early steps will be taken to establish special stations in Africa for meeting this need.

\section{Pests and Diseases}

In the past, the human diseases of the tropics and the pests and diseases of crops and stock controlled output. Malaria is of frequent occurrence, and its debilitating effects are still considerable. The lessons of certain operations in the Second World War have proved that a large measure of control over malaria is possible, and the value of D.D.T. in the control of mosquitoes in houses and villages has already been successfully demonstrated in British Guiana, Uganda, Mauritius and elsewhere, while a large-scale experiment in the Karpas peninsula of Cyprus has given such satisfactory results as to warrant wider trials in that Colony and to the planning of an all-island campaign against malarial-carrying mosquitoes in Mauritius.

The tsetse still holds under its control vast areas of Africa, and trypanosomiasis in man and in stock is still a controlling factor in certain areas. In Tanganyika, it is estimated that two-thirds of the total land area is infested by different species of tsetse flies; vast stretches of that territory are, in consequence, devoid of population. Much research work has been done on tsetse control and some advances have been made.

Among stock diseases, rinderpest, East Coast fever, pleuro-pneumonia and intestinal parasites have to be contended with. Progress has certainly been made by the veterinarians; but rinderpest is still a factor which cannot be regarded with equanimity in the African territories.

Locusts still cause damage to crops from time to time in Africa ; but marked advances have been made in our knowledge of the bionomics of the three species of locusts with which colonial territories in that continent have still to contend. The application of control measures based upon this knowledge is steadily continuing, but final success cannot yet be claimed.

Crop pests account for losses, and in certain areas they are a controlling factor. Those of cotton have received special attention, and the work of the entomologists of the Empire Cotton Growing Corporation has been outstanding. A considerable knowledge has been accumulated and this enables an assessment to be made with a fair measure of accuracy of the areas in which cotton cultivation can be extended and those in which such extension would at present be unwise. Control of certain pests of cotton and of several diseases has been achieved by the breeding of resistant strains, although it is still estimated that if the lygus pest in Uganda were controlled, output would be increased by 50 per cent. Similarly, there are still considerable losses during storage, especially in food crops or grains, and these are now under special investigation in West Africa.

Among plant diseases mention should be made of the witches' broom of cacao which has had devastat. ing effects in Trinidad and South America, the swollen shoot virus disease of cacao in West Africa, the die-back of eloves in Zanzibar, the mosaic disease of cassava, the Panama disease of bananas in the West Indies and the bunchy top disease of bananas and manila hemp in the East. The virus disease of cacao has already caused the loss of nearly one-third of cacao production in the Gold Coast. A special West African Cacao Research Institute has been established [see Nature, January 24, p. 117] and very considerable progress has been made. It is, however, unlikely that the disease will be finally defeated until new types immune or resistant to the virus have been found. Further expeditions in search of new strains of cacao from South America are contemplated and, in order to assist banana producers, a scientific expedition to collect wild species of Musa from south-east Asia is in process of being arranged.

\section{Marketing Arrangements}

Marketing arrangements and the prices of commodities have their place of importance in the efforts of all producers and agriculturists, as well as others. Price fluctuations often affect total production, and frequently the productivity of individual producers or groups of producers. When prices are low, agri- 
culturists tend to cut out maintenance works, and efficiency suffers. The fluctuations and the general trend of low prices for primary products between the two World Wars were not without their effect upon efficiency of production in the colonial territories.

The Second World War saw the introduction of bulk buying and selling of certain colonial commodities, and this system has introduced a system of agreements under which prices have been fixed by negotiation.

The value of such a system was appreciated by colonial producers, as it enabled them to plan their production ahead with some measure of confidence. Peasant producers have also benefited from, and have generally recognized the value of, the systems of price fixing which were adopted. There have, however, been fears that these arrangements could not be continued, and at the present moment further consideration is being given to the matter. Com. modity marketing organisations are being continued, and steps are being taken to build up price equaliza. tion funds so that when prices fall the producers will not suffer unduly. Contracts for purchase of some commodities now include provision for $(a)$ equipment replacement, $(b)$ the building up of price equalization funds, and $(c)$ expenditure on welfare amenities for the labourers employed.

The above arrangements relate to export commodities, and they should have a stabilizing and encouraging effect on production; but there are some who still contend that the contract periods are of too short a duration. Production for home consumption in the Colonies, especially of foodstuffs, would be stimulated if price-regulating methods similar to those contemplated under the recent United Kingdom Agriculture Act could be brought into effect.

\section{Social Organisation}

In the West Indies and some of the older Colonies, lands have from the first been held on forms of tenure and title similar to those prevailing in the United Kingdom, and social organisation has followed, with adaptations, the English pattern. In others, the forms of tenure have originated in indigenous customs which were an integral part of the social structure. In the African territories and also in some others, this structure, which is based upon the village, is built upon communities. Rights to particular plots of land are often recognized; but these rights are limited to the period of occupation, restricted as to suceession and qualified by membership of a kinship, clan or other group. These plots are usually small in size, and the community interest generally prevails so far as land is concerned. This is usually not the case in respect of the produce from the land.

Customary rights have undergone, and still are undergoing, a rapid process of change as the result of economic influences. The expansion of education, as well as the development of urban areas, and of mining, have had their effects. Introduction of new types of crops and of new methods of agriculture also have brought about important changes. The introduction of permanent tree crops such as cacao and coffee, for example, has resulted in a firm growth and expansion of the conception of ownership as against the previously held conception of a collective right in land derived from indigenous custom, and changes have been accelerated by the necessity for adjustment to the needs of modern economy of production and marketing. In some territories defined native reserves have been established, and in others there are to be found land tenures based upon the indigenous customs alongside those which have been introduced from elsewhere for alienated lands.

It is impossible to deal here, however, with the varying systems of land tenure which are found in colonial territories, to the tribal restraints which are sometimes imposed upon enterprise and initiative, or to discuss the strains and stresses which are resulting from the spread of education.

Productivity of land, however, depends as much upon sound systems of land tenure as upon improved agricultural practices, and any policy of development must increase the range of land matters and social issues to which colonial administrations will have to give urgent attention. It would seem that a solution of the social issues involved must lie in finding a balance between the advantages and disadvantages of the traditions of the past, the customs of the present and the needs of the future. Bold experiments may have to be made.

\section{Conclusion}

I have attempted, briefly, to review those factors which affect production in colonial agriculture. They are many and varied, and several of them are interdependent. In the early stages of colonial endeavour empirical measures sufficed, but these have gradually given place to methods which are being evolved on an ever-widening basis of knowledge. The man of science and the administrator are equally concerned, and a closely knit partnership between them must be established for the combined operations which are required.

Science has an important part to play. All research work must be planned in such a way that it is relevant to the objectives in view, and the utilization of this knowledge must be regarded as a duty of the administrative machine.

In agriculture, the scientific research worker should have full and frequent contact with production at all stages and with the persons engaged in that production. Without this contact, research is liable to become sterile and ineffective. Research organisa. tions for specific industries, when they can be afforded, have their value, as they do ensure that the results of their work are translated quickly into practice. When, however, research work is planned on a wider basis, steps must be taken to ensure that it is not divorced from those charged with helping the advancement of the cultivators of the land. The chain must be complete to be effective.

Equally, the human side nust not be disregarded. In many respects, it is the more important, as support for change or advancement can only be secured when the peoples concerned are convinced that such change will be for their advantage and worth the effort. Education has an important part to play here.

To the majority of the colonial peoples, agriculture is the foundation of their lives, their well-being and their hopes. With good will and understanding and with proper organisation, agricultural production can make great strides forward, but the traditions and customs of the colonial peoples must always be regarded sympathetically and with understanding. If the objective of greater production is made clear, enthusiasm aroused and willing co-operation secured, progress is certain. There are hazards which have to be surmounted, but with the aid of science, these will be overcome, and in future years they may be regarded as having been only the 'whistle points' along the track of development and progress. 